\title{
The Role of Integrated Healthcare Center in Giving Service to Community of Cot Teugoh, Pidie Sub-District, Pidie Regency
}

\author{
$\underline{\text { Salahuddin }}^{1}$ Ismail $^{2}$ \\ 1,2Universitas Iskandar Muda, Indonesia \\ Email: sal_salahuddin@yahoo.co.id
}

\begin{abstract}
:
Integrated Healthcare Center is carried out by the community at the village level, once a month. The purpose of implementing Posyandu is to find out the Role of Integrated Service Post Officers (Posyandu) in optimizing services to the community in Teugoh Cot Village, Pidie District, Pidie Regency and to find out the barriers of Integrated Healthcare Center in optimizing services to the community in Teugoh Cot Village, Pidie District Pidie Regency by using a qualitative descriptive approach. The informants of this study were 1 midwife, 1 nurse, 1 Posyandu officer, 2 community members. The results of the study found that, 1) The role of Poyandu officers in Teugoh Cot Village was not optimal. Integrated Healthcare Center officers come to Geuceu Iniem Village only once a month, namely the fourth month. Integrated Healthcare Center officers arrive at 10:00 until 11:30 noon. In carrying out their duties, Posyandu officers work less optimally and in serving the community less effectively, 2) Obstacles faced by Integrated Healthcare Center officers, lack of funds in implementing Integrated Healthcare Center programs, both medical equipment and others. Given that Integrated Healthcare Center is a program from the Public health center, very little funding was obtained to process the Posyandu program for the better.
\end{abstract}

\section{Keywords:}

the role of officers; community services; integrated healthcare center

\section{Introduction}

Health is one of the factors in achieving the level of social welfare of a society as mandated by the Law of the Republic of Indonesia Number 36 of 2009 concerning Health that health is a human right and one of the elements of well-being that must be realized in order to produce a healthy, smart and quality future generation. Needs to be prepared from the womb and maintained from birth. Various efforts have been made by the government by providing health services and increasing community participation in health development efforts.

Health problems are indeed a very serious phenomenon, especially in poor countries, where the majority of the population still has difficulty eating three meals a day or only consumes incomplete foods (without nutritious side dishes and without complete vitamin vegetables). For them, being able to eat white rice with salt or chili is still grateful because they can eat on that day. This kind of thing is also often found in several developing countries, including Indonesia. Therefore, it is necessary to create a quality of the population, especially in the health sector, not only considering physical or mental aspects, but also to produce a healthy, intelligent and quality next generation, which must be prepared from the womb and maintained from birth. Various efforts have been made by the government by providing health services and increasing community participation in health development efforts. 
In realizing the optimal health degree, the role of prime health service is needed. Health care is one of the determinants of the degree of public health. One of the targets is the Public Health Center. It is a functional unit which is a center of community health development that also fosters community participation and provides comprehensive and integrated services to the community in its working area in the form of main activities. (Hasibuan, 2020)

Integrated Healthcare Center as a center for community activities in health services efforts. Integrated Healthcare Center targets are infants, toddlers, pregnant women and nursing mothers. Integrated Healthcare Center which is an activity by and for the community, will give rise to community commitment, especially mothers and maintain the preservation of life and growth and development of children in their movements, Integrated Healthcare Center is monitored by selected cadres from their own area who are trained to carry out routine activities in Integrated Healthcare Center and outside the opening of Integrated Healthcare Center. A Integrated Healthcare Center cadre is a person who, because of his skills or abilities, was appointed, selected and or appointed to lead the development of a Integrated Healthcare Center in a place or village. The role of the cadres themselves, namely monitoring the growth of children or toddlers, conducting counseling related to maternal and child health so that the public knows and is able to practice what needs to be considered in handling children, pregnant or breastfeeding mothers and providing assistance for mothers who are unwell or sick if anyone needs to be referred to the hospital.

To improve the function and performance of Integrated Healthcare Center, it is the concern of all parties, so that the success of Integrated Healthcare Center is a shared responsibility. The implementation of Integrated Healthcare Center activities requires community participation, especially Integrated Healthcare Center cadres. Integrated Healthcare Center cadres come from community members who are willing to collaborate sincerely, are willing and able to carry out Integrated Healthcare Center activities, and are able to move the community to carry out Integrated Healthcare Center activities in order to provide effective services to the community so that the activities of Integrated Healthcare Center officers are felt by the community. In addition, work motivation is also one of the Integrated Healthcare Center's successes, with high motivation and being active in Integrated Healthcare Center activities that will improve the performance of Integrated Healthcare Center cadres. However, the problem is that there are still many cadres who are less motivated and less active in Integrated Healthcare Center activities. The motivation of Integrated Healthcare Center officers in Integrated Healthcare Center activities is a dominant factor that is very influential on the level of Integrated Healthcare Center utilization.

Integrated Healthcare Center activities that are running well will make it easy for the community to get basic health services, so that the quality of life of the people in old age is maintained well and optimally. Various Integrated Healthcare Center activities and programs for infants, toddlers, pregnant women, nursing mothers and postpartum mothers are very good and provide many benefits. They should try to make the best use of the Integrated Healthcare Center, so that the health of the elderly can be maintained and monitored properly. However, the phenomenon on the ground shows a different fact, Integrated Healthcare Center turned out to be only crowded at the beginning of the establishment, then the community who used the Integrated Healthcare Center was diminishing. 


\section{Review of Literature}

\subsection{Public Service Theory}

Public services involve a very broad aspect of life. In the life of the state, the government has the function of providing various public services needed by the community, ranging from services in the form of regulation or other services in order to meet the needs of the community in the fields of education, health, and others. According to Sinambela in Pasolong, (2013) is "As every activity carried out by the government of a number of people who have every activity that is beneficial in a collection or unity, and offers satisfaction even though the results are not tied to a product physically".

In the context of local government, public services as the provision of services or serve the needs of people or the community and / or other organizations that have interests in the organization, in accordance with the basic rules and procedures determined and intended to provide satisfaction to service recipients. Public services are activities provided by a person or group on the basis of a system or procedure that has been determined to meet the interests of the community. Public services must prioritize the public interest or the interests of the community. The implementation of services by the government to the community involves both parties to cooperate with each other.

\subsection{Theory of Human Resources}

Human resources are the capabilities that exist in a person, according to Marwansyah (2010) human resources can be interpreted as the utilization of human resources in the organization, which is done through the functions of human resource planning, recruitment and selection, human resource development, career planning and development, compensation and welfare, occupational safety and health, and industrial relations. All potential human resources affect the organization's efforts in achieving its goals. However advanced technology, information development, the availability of capital and adequate materials, if without human resources it is difficult for organizations to achieve their goals (Sutrisno, 2011).

\subsection{Theory of Role}

Role is a dynamic aspect in the form of actions or behavior carried out by someone who occupies or holds a position and carries out rights and obligations in accordance with his position. If a person performs this role properly, one will naturally hope that what is carried out is as desired by the environment. According to Duverger (2010) the term "role" was chosen well because he stated that every person is an actor in the society where he lives, also he is an actor who must play several roles such as professional actors.

Based on the description above, it can be stated that the role is a set of behaviors that are expected to be owned by people who are domiciled in the community. Someone who has a certain position can be said to be a role holder. A right is actually an authority to do or not do, while an obligation is a burden or duty. The role in an institution is related to the duties and functions, namely two things that can not be separated in the implementation of work by a person or institution. The task is a set of fields of work that must be done and attached to a person or institution in accordance with the functions they have. Function comes from the word in English function, which means something that contains uses or benefits.

\subsection{Integrated Healthcare Center concept}

Integrated Service Post or Integrated Healthcare Center is a unit of activities carried out by the community with mentors from health workers from Puskesmas aiming to achieve optimal health status (MOH RI, 2009). Integrated Healthcare Center is a center for family 
planning and health services that is managed and organized for and by the community with technical support from health workers in the framework of achieving the norms of Small Prosperous Happy Families (NKKBS).

By seeing some of the above meanings, the Integrated Healthcare Center is a place for communication of technology transfer in public health services and family planning carried out by the community, from the community and for the community with service support and technical guidance from health workers, which have strategic value for resource development humans from an early age in the context of fostering child survival (Child Survival) which is intended to maintain the survival of children from the fetus in the womb of the mother until the age of five (Fallen et al, 2010).

According to (Fallen et al., 2010) the purpose of forming a Integrated Healthcare Center is:

a. Reducing infant mortality (IMR), maternal mortality (pregnant women, childbirth and childbirth)

b. Cultivating NKKBS (Norms of Happy and Prosperous Small Families).

c. Increasing the participation and ability of the community to develop health and family planning activities and other activities that support the achievement of a healthy and prosperous society.

d. As a vehicle for the Prosperous Family Reproduction Movement, Family Resilience Movement and Prosperous Family Economic Movement.

\section{Research Method}

Research on the Role of Integrated Healthcare Center Officers in Optimizing Services to Communities in Cot Teugoh Village, Pidie District, Pidie District using qualitative research methods. (Sugiyono, 2012) states "Qualitative research is a research method used to examine natural conditions of objects, where researchers are key instruments. "Data collection from this study is not guided by theory but guided by facts found. The final results of this qualitative research produce meaningful data or information even new hypotheses or knowledge that can solve the problem.

According to Saryono, (2010) stated "Qualitative research is research that is used to investigate, discover, describe, and explain the quality or features of social influence that cannot be explained, measured or described through a quantitative approach." The problem in this research is to find out the role of Integrated Healthcare Center Officers in Optimizing Services to the Community in Cot Teugoh Village, Pidie District, Pidie Regency.

In this study, researchers focused on the role of Integrated Healthcare Center officers in optimizing services to the community in Teugoh Cot Village, Pidie District, Pidie District, including:

1. Role of Integrated Healthcare Center Officers in Optimizing Services for Communities in Cot Teugoh Village, Pidie District, Pidie Regency

Table 1. Dimensions and Indicators of Integrated Healthcare Center Officers

\begin{tabular}{|c|c|c|}
\hline No & Dimension & Indicator \\
\hline 1 & Service & $\begin{array}{l}\text { a. On time } \\
\text { b.Completeness }\end{array}$ \\
\hline 2 & Mobilize and direct & $\begin{array}{l}\text { a. Discipline } \\
\text { b. Responsible }\end{array}$ \\
\hline
\end{tabular}

Source: Data Processed in 2019 
2. Obstacles to Integrated Healthcare Center Officers in Optimizing Services for Communities in Cot Teugoh Village, Pidie District, Pidie Regency

Table 2. Dimensions and Indicators of Integrated Healthcare Center Officers' Constraints

\begin{tabular}{|c|l|ll|}
\hline No & \multicolumn{1}{|c|}{ Dimension } & \multicolumn{1}{|c|}{ Indicator } \\
\hline 1 & $\begin{array}{l}\text { The Role of Integrated } \\
\text { Healthcare Center Officers }\end{array}$ & $\begin{array}{l}\text { a. } \\
\text { b. Excellent service } \\
\text { c. }\end{array}$ & $\begin{array}{l}\text { Long distance } \\
\text { coople who don't want to }\end{array}$ \\
\hline 2 & Amenities & $\begin{array}{l}\text { a. } \\
\text { b. }\end{array}$ & $\begin{array}{l}\text { Lack of funding sources } \\
\text { spaciousness }\end{array}$ \\
\hline
\end{tabular}

Source: Data Processed in 2019

The interactive model referred to as follows:

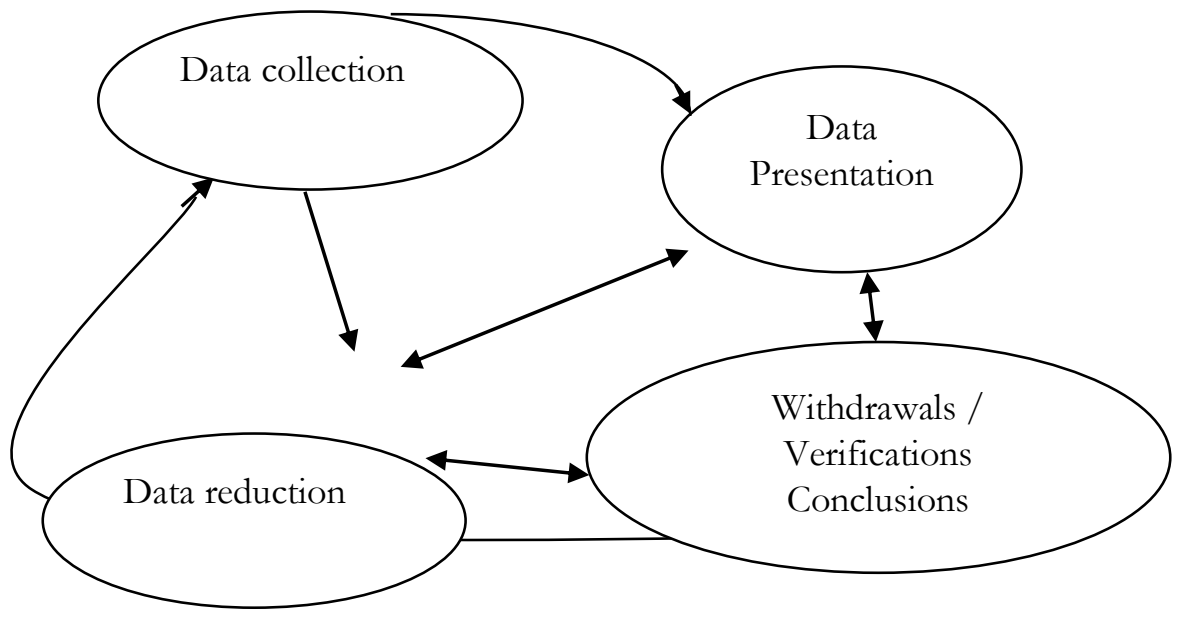

IV. Discussion

Cot Teungoh is a village in Asan settlement, Pidie District, Pidie Regency, Aceh Province. Cot Teungoh Village has rice fields and plantations that are very potential, affordable and fertile as well as several farms owned by several residents. But the agricultural area dominates more, and the majority of people work as farmers / planters, ranchers and the rest are civil servants (PNS) and laborers and unemployed. For farmers or planters they usually make use of privately owned vacant land for planting rice and vegetables such as tomatoes and melinjo. The results of their agriculture / plantations will usually be used as personal needs and some will be sold to the market. For breeders themselves, the community prefers raising livestock such as buffalo, cows, goats, native chickens and ducks.

Cot Teungoh village people still do not care about cleanliness and environmental health. Lots of garbage can be seen everywhere because there is no special place for garbage disposal. In the houses of residents there are also cow pens and are very close to their homes, this is feared to be a den of disease. For mutual cooperation itself, the community of Cot Teungoh village still does it, but within an unspecified period of time. People in this area are classified as still lacking in socializing and they tend to be closed. The children in Teungoh Cot Village lack the use of their free time for tutoring or additional study, they prefer to play with friends so that a lot of their time is wasted. The type of public transportation in the Cot Teungoh village is only RBT (ojek) but now most of the residents already have private vehicles. 
Cot Teungoh Village is included in the residential area of Asan, Pidie District, Pidie Regency with an area of $25 \mathrm{Ha}$. The use of 25 hectares of land includes 7 hectares of paddy fields, 3 hectares of dry land and 13 hectares of land and other 2 hectares. Administratively and geographically the village is divided into 4 hamlets, namely: Safe Hamlet, Damai Hamlet, Makmur Hamlet and Megembak Hamlet. Cot Teungoh Village is bordered by: In the north it is bordered by Keuniree Village, in the east it is bordered by Lampeudeu Village, in the south it is bordered by Tebeng dayah Village, in the west it is bordered by Cot Rheng Village.

Cot Teugoh Village with a population of 890 people. For more details about the population of the village can be seen in table 4.1 below.

Table 3. The population of Cot Teugoh Village

\begin{tabular}{|l|l|l|}
\hline No & Population & Amount / soul \\
\hline 1 & Number of family heads & $230 \mathrm{KK}$ \\
\hline 2 & Number of male population & 407 jiwa \\
\hline 3 & Total Female Population & 483 jiwa \\
\hline 4 & Total population & 890 jiwa \\
\hline
\end{tabular}

Source: Profile of Teugoh Cot Village

Regarding the facilities and infrastructure available in Cot Teugoh Village, it can be seen in table 4.2 below.

Table 4. Facilities and infrastructure of Teugoh Cot Village

\begin{tabular}{|l|l|l|}
\hline No & Facilities & Amount \\
\hline 1 & House & 209 unit \\
\hline 2 & Stall / shop & 4 unit \\
\hline 3 & Meunasah & 1 unit \\
\hline 4 & Coffee shop & 3 unit \\
\hline 5 & Primary & 1 unit \\
\hline 6 & Study center & 1 unit \\
\hline 7 & Soccer field & 1 unit \\
\hline 8 & College & 1 unit \\
\hline 9 & Public toilet / toilet & 1 unit \\
\hline 10 & Integrated Healthcare Center & 1 unit \\
\hline
\end{tabular}

Source: Profile of Teugoh Cot Village.

Regarding timely service, it is very necessary in a government institution, timely making someone who works becomes more disciplined especially those related to service. One of them is the services provided by puskesmas staff in the Integrated Healthcare Center program. The Integrated Healthcare Center program is an independent effort for the community to facilitate health services, especially the lower middle class community, which includes family planning services, maternal and child health, immunization, nutritional improvement and diarrhea prevention. This can be seen from the results of observations on the health service process carried out by Integrated Healthcare Center which is carried out routinely every month on the fourth week which is conducted at 10:00 to 12:00.

Then the results of an interview with Dian, a Integrated Healthcare Center nurse on Thursday, April 18, 2019, said that integrated service post officers provide good service to all Cot Teugoh communities, Pidie District, Pidie Regency. They come every month, at the end of the fourth month or week. The inspection is carried out at 10:00 until 12:00 noon. The service we provide is not long, only lasts 2 hours. This is due to the existence of other 
Gampongs which must also be visited to provide Integrated Healthcare Center services, especially for pregnant women and infants. The results of interviews with other informants that "Integrated Healthcare Center services are given once a month. Usually the service is done on Sunday, which is on the fourth week. The service provided is not long, only about 2 hours, therefore we the people here, have been waiting for Integrated Healthcare Center officers to come, so that all people who want to do the inspection, especially for pregnant women, and infants and mothers who are breastfeeding can not all be because the time from the officers is only two hours, so the people here are not satisfied with the services provided by the Integrated Healthcare Center staff. From the observations and interviews above it can be concluded that the service provided by the Integrated Healthcare Center is only once a month, but in reality the community expects the Integrated Healthcare Center staff to be made two or three times a month.

Integrated service post provides relief for the community of Cot Teugoh, District of Pidie, District of Pidie in treatment, especially for pregnant women and infants. Based on observations made by researchers, the Integrated Healthcare Center program has not been running optimally, while the results of the interview showed "All the people are enthusiastic waiting for the Integrated Healthcare Center staff to come, because the Integrated Healthcare Center service does not collect money from the community. Even so, the services provided to the community of Gugong Cot Teugoh District, Pidie District, Pidie Regency are not good, the officers are not friendly. Every question or complaint faced by the community is answered with modest means. The interview with one of the informants said that the Integrated Healthcare Center must be able to provide integrated services to the community, then it must provide good and satisfying services for the community.

The results showed that the Integrated Healthcare Center officers had performed their duties poorly, we felt the Integrated Healthcare Center program in Cot Teugoh Subdistrict, Pidie District, Pidie District was not fully implemented, because the Integrated Healthcare Center officers only came once a month. But for pregnant women and infants, a checkup once a month is not enough, because usually for pregnant women the examination must be two or three months.

Based on the results of the research above, it can be concluded that according to the Integrated Healthcare Center they already provide maximum service. Meanwhile, according to the community the Integrated Healthcare Center services provided to the community have not been maximized. From the two dimensions of service used the role of integrated service post officers (Integrated Healthcare Center) in optimizing service to the community in Cot Teugoh Subdistrict, Pidie District, Pidie Regency, it can be concluded that the services provided to the community in terms of timeliness and completeness of services are still not optimal, the community still complains and less satisfied with the officers' timeliness and completeness in serving the community.

Research results show that Integrated Healthcare Center officers are always responsible for the poyandu program to continue and in providing integrated services for the whole community. The responsibility that we provide in terms of our preparedness in terms of providing services once a month and providing vitamins and others. But according to the community Integrated Healthcare Center officers have provided less than optimal services to the community of Cot Teugoh Village, Pidie District, Pidie Regency. Namely the arrival once every month and less friendly with the community. 
Barriers Integrated Healthcare Center Officers in Optimizing Services to Communities in Cot Teugoh Village Pidie District Pidie Regency.

1). People Who Don't Want To Work Together

The existence of this Integrated Healthcare Center can certainly help rural communities in obtaining health services. However, the results of the study show that there are some people who do not come to Integrated Healthcare Center, this is because they have the money to come to a specialist, but not all of them, only a part of it. Most of the people who take part in the Integrated Healthcare Center program and want to be invited to work together. In the dimension of Integrated Healthcare Center Officers' role, namely excellent service, long distance and people who do not want to work, the role of integrated service post officers (Integrated Healthcare Center) is in optimizing service to the community in Teugoh Cot Village, Pidie District, Pidie Regency, it can be concluded that the prime services provided by officers Integrated Healthcare Center has provided good services for the community, the distance from home to Integrated Healthcare Center is not a problem but there is one thing that is still lacking, namely the people who want to work together because of their respective activities.

\section{2). Funds}

The results showed that the funds for Integrated Healthcare Center activities were very limited so that the Integrated Healthcare Center was only conducted once a month, given inadequate and inadequate. Apart from that the Public Healthcare Center did not get any funding injection, this was purely a program carried out by the puskesmas without other assistance. The source of funds is the biggest obstacle for the Integrated Healthcare Center in providing services to the community because the bodies of the officers are inadequate to provide extra services to the community.

\section{3). Lack of medical equipment}

Integrated Healthcare Center is only an integrated service, not like a puskesmas that has a lot of equipment. The results showed that the equipment for the needs of Integrated Healthcare Center is indeed very little, here there are only scales, injections and blood pressure. There are no good medical devices. Understandably, this is only a program from the health center, it also arrives once a month, so with makeshift equipment can help the community of Cot Teugoh Village, Pidie District, Pidie Regency.

Problems that concern the problem of drugs as a support in the implementation of the program are government policies that are distributed according to the needs and number of people in an area. The sub-district also helps in the provision of contraceptives in each village. In the view of medical personnel, the community tends to accept this program well. The community is ready to realize the program, especially regarding the involvement of PKK activists who are actively supporting Integrated Healthcare Center activities. Medical personnel also considered that facilities for buildings and others were still very minimal, the building itself was still very alarming, this can be seen with the implementation of Integrated Healthcare Center activities that are still hitching a ride at the home of one of the residents, so that efforts should be made to improve facilities so that they can support government programs regarding public health.

Medical personnel also saw that community involvement and perceptions were quite good, so that the program could be routinely carried out every month. Thus, it means that there must be serious attention from the district government to the existence of Integrated Healthcare Center buildings that have been riding residents' houses to carry out Integrated Healthcare Center activities. The lack of this facility is very difficult to realize due to the lack 
of injection of funds provided, making the Integrated Healthcare Center officers overwhelmed in overcoming the problem of funds. However, if there is government participation, it will facilitate the Integrated Healthcare Center officers.

This is in accordance with the opinion of Sadili Samsudin (2010: 1) HR or human resources are people who design and produce goods or services, oversee quality, market products, allocate financial resources, and formulate all organizational strategies and objectives. So it can be interpreted that, HR is an asset that is owned to carry out all operational activities. following:

Based on the results of the study several findings were disclosed including the

1. Services provided by Integrated Healthcare Center Officers are still ineffective, Integrated Healthcare Center services once a month.

2. Integrated Healthcare Center officers lack discipline, they arrive late and leave early, services are less than optimal

3. Integrated Healthcare Center officers do not provide excellent service, the distance is very close, but officers always arrive late.

4. Integrated Healthcare Center funds are still minimal and equipment is lacking.

\section{Conclusion}

1. The role of Poyandu officers in Teugoh Cot Village, Pidie District, Pidie Regency is not yet optimal. Integrated Healthcare Center officers come to Teugoh Cot Village, Pidie District, Pidie Regency only comes once a month, namely in the fourth month. Integrated Healthcare Center officers arrive at 10:00 until 11:30 noon. In carrying out their duties, Integrated Healthcare Center officers work less optimally, namely serving the community less effectively. When the community arrives late to the Integrated Healthcare Center site, the Integrated Healthcare Center officer no longer wants to handle the community who arrives late, on the contrary if the Integrated Healthcare Center officer arrives late, the community is not complaining and remains happy at the presence of the Integrated Healthcare Center officer.

2. Obstacles faced by Integrated Healthcare Center officers are, lack of costs in implementing Integrated Healthcare Center programs, both medical equipment and others, Lack of medical equipment. Considering that Integrated Healthcare Center is a program from the Puskesmas, very little funding was obtained to process the Integrated Healthcare Center program for the better. So the Integrated Healthcare Center that is carried out in Cot Teugoh Village, Pidie District, Pidie Regency is just modest

\section{References}

Ahmadi, Rulam. (2014). Metodologi Penelitian Kualitatif. Yogyakarta : Ar-. Ruzz Media. Bungin, Burhan. (2011). Penelitian Kualitatif. Jakarta: Kencana Predana Media. Group.

Deri, Putra. (2015), Faktor Yang Berhubungan Dengan Pemanfaatn Integrated Healthcare Center Lansia Di Wilayah Kerja Puskesmas Sikpak Kota Pariaman Tahun 2015, Skripsi, Universitas Andalas Fakultas Kesehatan Masyarakat.

Dewi, Hanggraeni.( 2012). Manajemen Sumber Daya Manusia. Jakarta : FEUI

Devi, Punikasari. (2010), Peran Integrated Healthcare Center Dalam Meningkatkan Kualitas

Kesehatan Masyarakat Di Dusun Karangwatu, Desa Pucung Rej, Kecamatan Muntilan, Kabupaten Magelang, skripsi, universitas yogyakarta jurusan pendidikan sejarah. 
Duverger, Maurice. (2010). Sosiologi Politik. Diterjemahkan oleh Jakarta: PT.Grafindo Persada.

Dwiyanto, Agus. (2015). Manajemen Pelayan Publik: Peduli, Inklusif, dan Kolaboratif. Yogyakarta: Universitas Gajah Mada Press.

Fallen, R dan R. Budi Dwi K. (2010). Catatan Kuliah Keperawatan Komunitas. Yogyakarta: Nuha Medika.

Hanggraeni. Dewi. (2012). Manajemen Sumber Daya Manusia. Jakarta : FEUI

Himawan, Wijarnako. (2011). Power Branding : Membangun Merek Unggul dan Organisasi Pendukungnya. Jakarta: Quantum Bisnis \& Manajemen.

Hardiansyah. (2011). Kualitas Pelayanan Publik. Yogyakarta: Gava Media.

Hasibuan, S. (2020). Relationship of Family Income and Family Support with Maternal Reference in Pregnant Women in Pantai Cermin BEmONC, Langkat District. Budapest International Research and Critics Institute-Journal (BIRCI-Journal). p. 486493

Marwansyah. (2010). Manajemen Sumber Daya Manusia. Alfabeta:Bandung.

Moleong, Lexy J. (2012). Metodologi Penelitian Kualitatif. Bandung : PT Remaja

Rosdakarya., (2013). Budaya Organisasi Kepemimpinan Dan Kinerja. Jakarta: PT. Fajar. Iterpratama Mandiri.

Pasolong, Hasibuan. (2013) Kepemimpinan Birokrasi. Bandung : CV.Alfabeta.

Putra, Fadhilla. (2012). New Public Governance. Diterjemahkan oleh Malang: UB Press.

Ratminto \& Atik Septi Winarsih. (2013). Manajemen Pelayanan. Yogyakarta : Pustaka Belajar.

Samsudin, Sadili. (2010). Manajemen Sumber Daya Manusia. Bandung : Pustaka Setia.

Sanerya Hendrawan, Indraswari, Sylvia yazid, (2012). Pengembangan Human Capital, Yogyakarta :Graha Ilmu.

Sarwono. (2012). Psikologi Remaja. Jakarta: PT. Raja Grafindo.

Saryono. (2010). Metodologi Penelitian Kebidanan. Nuha. Medika. Jakarta.

Santoso, Pandji. (2010). Administrasi Publik, Teori dan Aplikasi Good Governance. Bandung: PT. Refika Aditama.

Sinambela, L.P. (2010). Reformasi Pelayanan Publik;Teori,Kebijakan dan Implementasi, cetakan kelima. Jakarta: PT. Bumi Aksara.

Soekanto, Soerjono. (2011), Sosiologi Suatu Pengantar. Jakarta: Rajawali Pers.

Sedarmayanti. (2010). Sumber Daya Manusia dan Produktivitas Kerja. Jakarta:

Sutrisno, (2011), Manajemen Sumber Daya Manusia, Jakarta: Kencana.

Sugiyono. (2012). Metode Penelitian Kuantitatif Kualitatif dan R\&D. Bandung: Alfabeta.

Keputusan Menteri Pendayagunaan Aparatur Negara Nomor 63 Tahun 2003.

Undang-Undang No. 11 Tahun 2009 tentang Kesejahteraan Sosial.

Undang-undang Republik Indonesia Nomor 36 Tahun 2009.

Undang-undang Indonesia Nomor 18 Tahun 2014 Tentang Pengawasan di Bidang Kesehatan.

Keputusan Menteri Pendayagunaan Aparatur Negara Nomor 63/ KEP/ M.PAN/7/2003

Tentang Pedoman Umum Penyelenggaraan Pelayanan Publik merupakan hal yang sangat penting dalam meningkatkan kualitas pelayanan publik. 